UDC 576.533

\title{
Comparison of proliferative activity of Wharton jelly mesenchymal stem cells in cultures under various gas conditions
}

\author{
N. S. Shuvalova ${ }^{1}$, V. A. Kordium ${ }^{1,2}$ \\ ${ }^{1}$ State Institute of Genetic and Regenerative Medicine, NAMS of Ukraine \\ 67, Vyshhorodska Str., Kyiv, Ukraine, 04114 \\ 2 Institute of Molecular Biology and Genetics, NAS of Ukraine \\ 150, Akademika Zabolotnoho Str., Kyiv, Ukraine, 03680 \\ riyena@yandex.ua
}

\section{Introduction}

Numerous experimental works and theoretical analysis, focused on mesenchymal stem cells (MSCs), allow considering them not only as an interesting object of studies on fundamental processes of fetal and adult life, but also as a key element in various methods of regenerative therapy. A promising position of MSCs in the cell-based therapeutic strategies results from their high proliferative and differential potential, unique paracrine effects and immune properties $[1,2,3]$.

MSCs were first identified in bone marrow and described as a population of non- hematopoietic multipotent cells $[4,5]$. Further studies showed that the cells with similar properties can be found in both tissues of adult organism and birth-associated tis- sues: amnion, placenta and umbilical cord [6]. According to the current literature, the latter are often defined as the «perinatal» stem cells, possessing the properties of both adult and embryonic stem cells [7]. Among them, MSCs from umbilical cord matrix Wharton jelly (WJ-MSCs), are thought to be especially attractive. The formation of WJ-MSCs population at the early stages of embryogenesis [8], permits them to preserve the features of the embryonic stem cells $[7,9,10]$, prominent differentiation [11], immune [12] and paracrine properties [13]. At the same time, they possess the characteristics of adult somatic mesenchymal multipotent stromal cells [14], determined by the International Society for Cellular Therapy [15].

One of the most important characteristics of MSCs, particularly for the clinical usage, is their prolifera-

\footnotetext{
(C) 2015 N.S. Shuvalova et al.; Published by the Institute of Molecular Biology and Genetics, NAS of Ukraine on behalf of Biopolymers and Cell. This is an Open Access article distributed under the terms of the Creative Commons Attribution License (http://creativecommons.org/licenses/by/4.0/), which permits unrestricted reuse, distribution, and reproduction in any medium, provided the original work is properly cited
} 
tive activity. For instance, according to the literature, during the treatment of acute «graft-versus-host» disease, patients received $2 \times 10^{6}-8 \times 10^{6} \mathrm{MSCs} / \mathrm{kg}$ body weight [16]. The percent of MSCs in their classical source - bone marrow for the newborns is $0.01 \%$, and decreases to $0.001-0.005 \%$ with aging [17]. Therefore, it is vitally important to develop the cultivation technologies, which would allow maximal cell multiplication with preservation of the MSCs therapeutically relevant properties. The complexity of this task is related to the process of cultivation itself. Some works report that a long-term cultivation increases the risks of genetic abnormalities [18], thus a reasonable approach to provide the most effective MSCs cultivation should grant obtaining the maximal number of cells while minimizing the duration of culturing.

In the organism, a crucial role in the regulation of MSCs behavior and preservation of their properties belongs to their natural site of localization - «stem cell niche». Its components include the extracellular matrix, surrounding cells and signal molecules, produced by them. One of the key factors of niche regulation is the oxygen concentration, which is generally lower comparing not only to ambient atmospheric concentration, but also to that in other regions of the tissue. For instance, the oxygen concentration in bone marrow ranges from $2 \%$ to $7 \%$, depending on the distance from capillary, and MSCs locate in the areas remote from vessels, which are, the most «hypoxic» zones [19]. Thus, the generally accepted environmental conditions of $\mathrm{CO}_{2}$-incubator, where the oxygen concentration is similar to atmospheric, are actually «hyperoxic» for MSCs, which inevitably leads to the oxidative damages $[20,21]$. Taking this into account, the MSCs cultivation at physiological oxygen concentrations, often referred to as «hypoxic», is considered to be a perspective approach [22-24].

The studies focused on the influence of hypoxic conditions on the MSCs cultivation reported their beneficial effect on multiplication, reducing oxidative stress, and engraftment in the transplantation [25-28]. However, it is hard to compare the results obtained in different works. MSCs, used in various studies, originate from different sources, the design of experiments varies from short-term preconditioning to a long-term cultivation, and the $\mathrm{O}_{2}$ concentrations used range from $1.5 \%$ to $8 \%$. The works on the influence of hypoxic conditions on WJ-MSCs, still remain rare cases.

Generally, the gas mixtures used for cultivation include nitrogen as a major «filling» component [29-31]. However, recent works have shown the cytoprotective effect of noble (or inert) gases (argon and xenon) on the cell cultures [32]. Taking this into account, we hypothesized, that using the «hypoxic» gas mixture based on the noble gas would enhance the beneficial effect of physiological oxygen concentration on the MSCs culture.

Thus, the aim of the present work was to optimize the MSCs cultivation using physiological oxygen concentrations, and to compare the effects of «hypoxic» nitrogen- and argon-based gas mixtures on the human WJ-MSCs proliferation.

\section{Materials and Methods}

MSCs were obtained from WJ of umbilical cord (UC) from three healthy donors (39-40 weeks of gestation, normal delivery), after obtaining the informed written consent, in Kyiv maternity clinic $\mathrm{N}$ 5. The cells were isolated using the explant method [33]. The UC fragment $(5-10 \mathrm{~cm})$ was washed with PBS, the vessels were mechanically removed. WJ was mechanically sliced, the fragments were placed in the cultural flacks, $75 \mathrm{~cm}^{2}$, containing complete growth medium (DMEM with low glucose (PAA Austria) supplemented with $10 \%$ fetal bovine serum (PAA, Austria), glutamine $2 \mathrm{mM}$ (PAA, Austria), penicillin $100 \mathrm{U} / \mathrm{ml}$ (Arterium, Ukraine), streptomycin $100 \mu \mathrm{g} / \mathrm{ml}$ (Arterium, Ukraine). The first adherent cells were visible on 7-10 day. After 14 days the clones reached $70-80 \%$ confluence, and the cells were passed using trypsin-EDTA $(0.1 \%$ trypsin and $0.02 \%$ EDTA) solution. At the first passage the cells were characterized for the surface marker proteins CD90, CD73, CD105 expression (over $85 \%$ positive), using flow cytometry ( BD FACS Aria) with fluorescein- and rhodamine-conjugated antibodies (UsBiological, USA). For microscopy, inverted microscope Leica DMIL was used. 
From the first passage, MSCs were seeded on plastic flacks $\left(25 \mathrm{~cm}^{2}\right)$ at a density of 75,000 per flack and cultivated during 5 passages in the nitrogen-based gas mixture (3\% oxygen, $4 \%$ carbon dioxide, $93 \%$ nitrogen) and argon-based gas mixture (3\% oxygen, $4 \%$ carbon dioxide, $93 \%$ argon), 7 days before replating. The control group was maintained under standard $\mathrm{CO}_{2}$ incubator conditions. For creating the hypoxic conditions, the cultural flacks with cells were placed in polyethylene bags with hermetical clasp «ZipLock». The bags were washed twice with the oxygen-free gas mixture, containing $4 \% \mathrm{CO}_{2}$ and $96 \%$ nitrogen or argon (depending on the group), and after that were filled with the cultivation gas mixture (see above). The bags were placed in the vacuum containers (Scarlet). The percentage «liquid media/gas» for normal gas exchange must be 1:100 [34], the volume of gas mixture must be no less than 0.71 . The volume of bags used was 1.51 .

At each passage, after 7 days of culturing, the cells were replated using trypsin-EDTA $(0.1 \%$ trypsin and $0.02 \%$ EDTA) solution and counted in hemocytometer (Goryaev chamber). Population doubling was calculated as: $\mathrm{PD}=\log (\mathrm{Nf} / \mathrm{Ni}) / \log 2$, where $\mathrm{Nf}$ - final cell number; $\mathrm{Ni}$ - initial cell number [22].

The data on cell numbers are represented as mean \pm standard deviation for 3 samples. Statistical significance was determined using Mann-Whitney U-test at $\mathrm{P}<0.05$.

\section{Results and Discussion}

WJ-MSCs were expanded for five consecutive passages under $3 \% \mathrm{O}_{2}$, in the gas mixtures based on nitrogen, argon, and ambient $\mathrm{O}_{2}$ concentration (near-

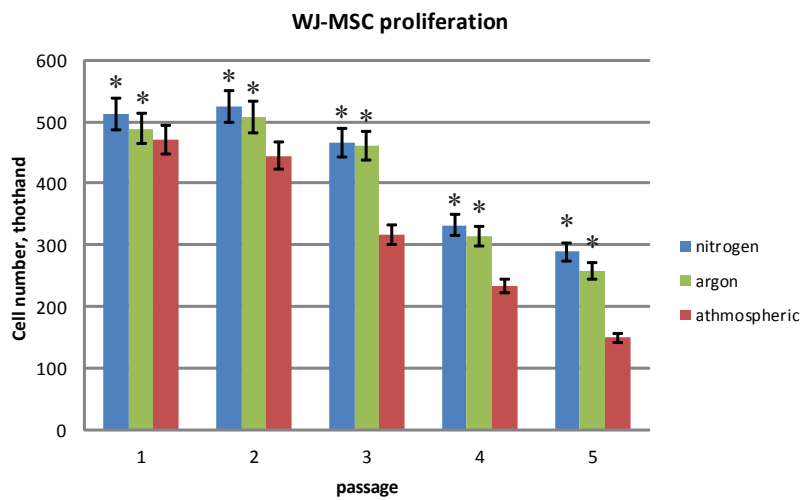

Fig. 1. Numbers of cells in WJ-MSCs cultures at 1-5 passages, after 7 days of cultivation. «Nitrogen»- nitrogen-based gas mixture (3\% oxygen, $4 \%$ carbon dioxide, $93 \%$ nitrogen), «argon» argon-based gas mixture ( $3 \%$ oxygen, $4 \%$ carbon dioxide, $93 \%$ argon), «atmospheric» $-\mathrm{CO}_{2}$ incubator conditions. * $-\mathrm{P}<$ $0.05)$

ly $20 \%$ ) in $\mathrm{CO}_{2}$-incubator. In order to assess the proliferation activity, the cells were counted at each passage. The results, summarized in Table 1 an Figure 1 , show a final number of cells after 7 days of cultivation.

The proliferation level of WJ-MSCs, cultured at $3 \%$ $\mathrm{O}_{2}$, in both gas mixtures was significantly higher compared to that of WJ-MSCs under the $\mathrm{CO}_{2}$-incubator conditions. This was observed at each passage.

Interestingly, a comparison of the culture growth rates at different passages within each group allows distinguishing two separate «phases» during the cultivation. The first «phase» - at the first and second passages the cultures had practically similar proliferation levels. The second «phase» - beginning from the third passage, a progressive decrease in proliferation can be observed with each new passing. For WJ-

Table 1. Numbers of cells in WJ-MSCs cultures at 1-5 passage, after 7 days of cultivation.

«Nitrogen» - nitrogen-based gas mixture (3\% oxygen, $4 \%$ carbon dioxide, $93 \%$ nitrogen), «argon» - argon-based gas mixture (3\% oxygen, $4 \%$ carbon dioxide, $93 \%$ argon), «atmospheric» - $\mathrm{CO}_{2}$ incubator conditions $(\mathrm{P}<0.05)$

\begin{tabular}{|c|c|c|c|}
\hline N of passage & Nitrogen & Argon & Atmospheric \\
\hline 1 & $513.68 \pm 9.58$ & $488.3 \pm 20.91$ & $471.72 \pm 9.7$ \\
2 & $525.47 \pm 7.32$ & $508.6 \pm 25.69$ & $444.58 \pm 19.07$ \\
3 & $465.6 \pm 2.91$ & $460.67 \pm 21.06$ & $317.53 \pm 25.23$ \\
4 & $332.39 \pm 15.16$ & $315.27 \pm 16.22$ & $233.62 \pm 5.1$ \\
5 & $288.93 \pm 11.39$ & $258 \pm 26.17$ & $149.77 \pm 36.93$ \\
\hline
\end{tabular}


MSCs, cultured in the gas mixtures, this tendency was less pronounced.

At the first passage of culture under $3 \% \mathrm{O}_{2}$ in the nitrogen-based and argon-based gas mixtures, the final number of expanded WJ-MSCs was respectively 6.8 and 6.4 times higher, was higher comparing to cells from control group (6.1-fold increase). The results for the second passage were 6.9, 6.4 and 6 respectively. The data for the entire culture duration are summarized in Table 2.

The PD estimation showed that, despite a general decrease in the number of PD up to the 5th passage, the MSCs cultured under the physiological oxygen tension, had generally higher intensity of division (Table 3 ).

The proliferative activity is an important criterion for an estimation of the state of culture, and a suffi-

Table 2. Multiplication in WJ- MSCs cultures at 1-5 passages, $n$-fold increase in number after 7 days of cultivation

\begin{tabular}{|c|c|c|c|}
\hline Passage & Nitrogen & Argon & Atmospheric \\
\hline 1 & 6.8 & 6.4 & 6.1 \\
2 & 6.9 & 6.8 & 6 \\
3 & 6 & 6 & 4.1 \\
4 & 4.4 & 4.2 & 3.1 \\
5 & 3.8 & 3.4 & 1.9 \\
\hline
\end{tabular}

N o te. «Nitrogen» - nitrogen-based gas mixture (3\% oxygen, $4 \%$ carbon dioxide, $93 \%$ nitrogen), «argon» - argon-based gas mixture (3\% oxygen, $4 \%$ carbon dioxide, $93 \%$ argon), « atmospheric» $-\mathrm{CO}_{2}$ incubator conditions $(\mathrm{P}<0.05)$

Table 3. Population doublings in WJ-MSCs cultures at 1-5 passages, after 7 days of cultivation

\begin{tabular}{|c|c|c|c|}
\hline N of passage & Nitrogen & Argon & Atmosperic \\
\hline 1 & 2.76 & 2.68 & 2.61 \\
2 & 2.79 & 2.76 & 2.59 \\
3 & 2.59 & 2.59 & 2.04 \\
4 & 2.15 & 2.07 & 1.64 \\
5 & 1.95 & 1.78 & 1 \\
\hline
\end{tabular}

N o te. «Nitrogen» - nitrogen-based gas mixture (3\% oxygen, $4 \%$ carbon dioxide, $93 \%$ nitrogen), «argon» - argon-based gas mixture (3\% oxygen, $4 \%$ carbon dioxide, $93 \%$ argon), « atmospheric» $-\mathrm{CO}_{2}$ incubator conditions $(\mathrm{P}<0.05)$ cient activity is necessary for practical application. It strongly depends on the conditions of cultivation, each factor of environment having its own mechanisms of influence. In this context, proliferation itself can be considered a subject of research. In the present work, the proliferation rates of MSCs cultures, expanded under physiological oxygen tensions $-3 \%$, in the mixtures based on nitrogen and argon, were validated. The estimation of cells number at $1-5$ passages showed significantly higher numbers in the gas mixtures at each passage, comparing to the groups from control $\mathrm{CO}_{2}$-incubator. The results also revealed a higher level of PD under hypoxic conditions up to the 5 th passage. The effect of mild hypoxia appeared to be stimulating in both mixtures, at the same time, the differences between these conditions were detected.

Although a high variability in the object and methods of studies on hypoxia complicates the comparison of results, we can assume that the tendencies, observed in the present work, are generally in line with those described in literature. Nevertheless, it is important to point out the differences. The work by Basciano et al. revealed the slowing of culture growth at early passages under hypoxic conditions [22]. We have not observed any similar effect. Ren et al detected the morphological signs of accelerated cellular senescence in hypoxic conditions, probably associated with a higher population doublings number [35]. In the present study there was no evidence of degenerative changes of morphology in the cultures expanded under hypoxic conditions (data not shown).

The current literature distinguishes several potential mechanisms of physiological oxygen concentrations impact. First, the reactive oxygen species are one of the major sources of DNA damage [36]. Hypoxic conditions were shown to prevent the accumulation of damages of genetic apparatus, which in control groups can be detected since the second passage [17]. This can play an important role during long-term cultivation. Next, the researches show that hypoxic conditions increase the level of cytokine receptors expression, as well as the production of growth factors. In this case, hypoxia « sensibilizes « the cells to serum growth factor, and to that produced by the cells themselves [27]. Next, there are data 
Comparison of proliferative activity of Wharton jelly mesenchymal stem cells in cultures under various gas conditions

showing that hypoxia activates the signal cascades of cell survival. The cultures in hypoxic conditions are shown to have lower levels of necrosis comparing to those cultured under the ambient oxygen concentration [24]. Each of these mechanisms can contribute to the general effect of physiological oxygen concentration, and determination of their roles is still considered the question of interest.

To date, the data about the effect of noble gases on MSCs culture are still lacking. There are only few works conducted to determine the influence of inert gases (xenon and argon), which demonstrated a cytoprotective effect on the cell cultures of neural origin. For example, the modeling of ischemic and traumatic damages of hippocampal slice culture in gas mixtures, containing various concentrations of $\operatorname{argon}(25 \%, 50 \%$ and $74 \%)$ and atmospheric oxygen concentration (21\%), showed a decreased level of cellular death compared to the control samples. The underlying mechanisms are unknown [32]. Though, Fahlenkamp et al. demonstrated the activation of ERK 1/2, kinase that plays an important role in the processes of cells proliferation and survival, in the primary cultures of mouse embryonic astrocytes and neurons, cultured under $20 \% \mathrm{O}_{2}$ and $50 \%$ argon [37]. It is possible that MSCs possess the similar mechanism.

The present work showed that the level of proliferation of WJ-MSCs, cultured in argon-based gas mixtures was higher comparing to WJ-MSCs from $\mathrm{CO}_{2}$-incubator conditions, but lower than that for the cultures from nitrogen-based mixtures. To explain these results, further research is required. Besides, taking into account the variety of existing cultivation protocols, changing the cultural strategy could probably lead to a different effect.

\section{Conclusions}

Cultivation of human WJ-MSCs under $3 \% \mathrm{O}_{2}$ in gas mixtures, based on nitrogen and argon, had a beneficial effect on the cells proliferative activity and preservation of multiplication potential. The hypoxic argon- and nitrogen-based gas mixtures had different effects. The highest intensity of cell proliferation was observed in the nitrogen-based mixtures.

\section{REFERENCES}

1. Caplan AI. Why are MSCs therapeutic? New data: new insight. J Pathol. 2009;217(2):318-24.

2. Xin H, Li Y, Chopp M. Exosomes/miRNAs as mediating cellbased therapy of stroke. Front Cell Neurosci. 2014;8: 377.

3. Khubutiya MS, Vagabov AV, Temnov AA, Sklifas AN. Paracrine mechanisms of proliferative, anti-apoptotic and antiinflammatory effects of mesenchymal stromal cells in models of acute organ injury. Cytotherapy. 2014;16(5):579-85.

4. Friedenstein AJ, Piatetzky-Shapiro II, Petrakova KV. Osteogenesis in transplants of bone marrow cells. J Embryol Exp Morphol. 1966;16(3):381-90.

5. Friedenstein AJ, Gorskaja JF, Kulagina NN. Fibroblast precursors in normal and irradiated mouse hematopoietic organs. Exp Hematol. 1976;4(5):267-74.

6. Shachpazyan NK, Astrelina TA, Yakovleva MV. Mesenchymal stem cells from various human tissues: biological properties, assessment of quality and safety for clinical use. CTTE 2011;7(1): 23-33.

7. Taghizadeh RR, Cetrulo KJ, Cetrulo CL. Wharton's Jelly stem cells: future clinical applications. Placenta. 2011;32 (Suppl 4):S311-5.

8. Wang XY, Lan Y, He WY, Zhang L, Yao HY, Hou CM, Tong Y, Liu YL, Yang G, Liu XD, Yang X, Liu B, Mao N. Identification of mesenchymal stem cells in aorta-gonad-mesonephros and yolk sac of human embryos. Blood. 2008;111(4):2436-43.

9. Fong CY, Richards M, Manasi N, Biswas A, Bongso A. Comparative growth behaviour and characterization of stem cells from human Wharton's jelly. Reprod Biomed Online. 2007;15(6):708-18.

10. Zhang H, Zhang B, Tao Y, Cheng $M, H u J, X u M$, Chen $H$. Isolation and characterization of mesenchymal stem cells from whole human umbilical cord applying a single enzyme approach. Cell Biochem Funct. 2012;30(8):643-9.

11. Lindenmair A, Hatlapatka T, Kollwig G, Hennerbichler S, Gabriel C, Wolbank S, Redl H, Kasper C. Mesenchymal stem or stromal cells from amnion and umbilical cord tissue and their potential for clinical applications. Cells. 2012;1 (4):1061-88.

12. Le Blanc K. Immunomodulatory effects of fetal and adult mesenchymal stem cells. Cytotherapy. 2003;5(6):485-9.

13. Hsieh JY, Wang HW, Chang SJ, Liao KH, Lee IH, Lin WS, Wu CH, Lin WY, Cheng SM. Mesenchymal stem cells from human umbilical cord express preferentially secreted factors related to neuroprotection, neurogenesis, and angiogenesis. PLoS One. 2013;8(8):e72604.

14. Troyer DL, Weiss ML. Wharton's jelly-derived cells are a primitive stromal cell population. Stem Cells. 2008;26(3): 591-9.

15. Dominici M, Le Blanc K, Mueller I, Slaper-Cortenbach I, Marini F, Krause D, Deans R, Keating A, Prockop Dj, Horwitz $E$. Minimal criteria for defining multipotent mesenchy- 
mal stromal cells. The International Society for Cellular Therapy position statement. Cytotherapy. 2006;8(4):315-7.

16. Kebriaei P, Isola L, Bahceci E, Holland K, Rowley S, Mc Guirk $J$, Devetten M, Jansen J, Herzig R, Schuster M, Monroy R, Uberti J. Adult human mesenchymal stem cells added to corticosteroid therapy for the treatment of acute graft-versus-host disease. Biol Blood Marrow Transplant. 2009;15 (7):804-11.

17. Lund TC, Kobs A, Blazar BR, Tolar J. Mesenchymal stromal cells from donors varying widely in age are of equal cellular fitness after in vitro expansion under hypoxic conditions. Cytotherapy. 2010;12(8):971-81.

18. Rubio D, Garcia-Castro J, Martín MC, de la Fuente R, Cigudosa JC, Lloyd AC, Bernad A. Spontaneous human adult stem cell transformation. Cancer Res. 2005;65(8): 3035-9.

19. Watt FM, Hogan BL. Out of Eden: stem cells and their niches. Science. 2000;287(5457):1427-30.

20. Choo KB, Tai L, Hymavathee KS, Wong CY, Nguyen PN, Huang CJ, Cheong SK, Kamarul T. Oxidative stress-induced premature senescence in Wharton's jelly-derived mesenchymal stem cells. Int J Med Sci. 2014;11(11): 1201-7.

21. Kim M, Kim C, Choi YS, Kim M, Park C, Suh Y. Age-related alterations in mesenchymal stem cells related to shift in differentiation from osteogenic to adipogenic potential: implication to age-associated bone diseases and defects. Mech Ageing Dev. 2012;133(5):215-25.

22. Basciano L, Nemos C, Foliguet B, de Isla N, de Carvalho $M$, Tran N, Dalloul A. Long term culture of mesenchymal stem cells in hypoxia promotes a genetic program maintaining their undifferentiated and multipotent status. BMC Cell Biol. 2011;12:12.

23. Dos Santos F, Andrade PZ, Boura JS, Abecasis MM, da Silva CL, Cabral JM. Ex vivo expansion of human mesenchymal stem cells: a more effective cell proliferation kinetics and metabolism under hypoxia. J Cell Physiol. 2010; 223(1):27-35.

24. Lavrentieva A, Majore I, Kasper C, Hass R. Effects of hypoxic culture conditions on umbilical cord-derived human mesenchymal stem cells. Cell Commun Signal. 2010;8:18.

25. Krinner A, Zscharnack M, Bader A, Drasdo D, Galle J. Impact of oxygen environment on mesenchymal stem cell expansion and chondrogenic differentiation. Cell Prolif. 2009; 42(4):471-84.

26. Fehrer C, Brunauer R, Laschober G, Unterluggauer H, Reitinger S, Kloss F, Gülly C, Gassner R, Lepperdinger G. Reduced oxygen tension attenuates differentiation capacity of human mesenchymal stem cells and prolongs their lifespan. Aging Cell. 2007;6(6):745-57.

27. Hung SC, Pochampally RR, Hsu SC, Sanchez C, Chen SC, Spees J, Prockop DJ. Short-term exposure of multipotent stromal cells to low oxygen increases their expression of CX3CR1 and CXCR4 and their engraftment in vivo. PLoS One. 2007; 2(5):e416.

28. Annabi B, Lee YT, Turcotte S, Naud E, Desrosiers RR, Champagne M, Eliopoulos N, Galipeau J, Béliveau R. Hypoxia promotes murine bone-marrow-derived stromal cell migration and tube formation. Stem Cells. 2003;21(3):337-47.

29. D'Ippolito G, Diabira S, Howard GA, Roos BA, Schiller PC. Low oxygen tension inhibits osteogenic differentiation and enhances stemness of human MIAMI cells. Bone. 2006;39 (3):513-22

30. Carrancio S, López-Holgado N, Sánchez-Guijo FM, Villarón E, Barbado V, Tabera S, Díez-Campelo M, Blanco J, San Miguel JF, Del Cañizo MC. Optimization of mesenchymal stem cell expansion procedures by cell separation and culture conditions modification. Exp Hematol. 2008;36(8): 1014-21.

31. Ivanovic Z, Hermitte F, Brunet de la Grange P, Dazey B, Belloc F, Lacombe F, Vezon G, Praloran V. Simultaneous maintenance of human cord blood SCID-repopulating cells and expansion of committed progenitors at low $\mathrm{O}_{2}$ concentration (3\%). Stem Cells. 2004;22(5):716-24.

32. Loetscher PD, Rossaint $J$, Rossaint R, Weis $J$, Fries $M$, Fahlenkamp A, Ryang YM, Grottke O, Coburn M. Argon: neuroprotection in in vitro models of cerebral ischemia and traumatic brain injury. Crit Care. 2009;13(6):R206.

33. Maslova OO, Shuvalova NS, Sukhorada OM, Zhukova SM, Deryabina OG, Makarenko MV, Govseiev DO, Kordium VA. Heterogeneity of umbilical cords as a source for mesenchymal stem cells. Dataset Pap Biol. 2013;2013:1-4.

34. Freshney RI. Animal cell culture a practical approach. Oxford University Press; 2nd edition 1986; 264 p.

35. Ren H, Cao Y, Zhao Q, Li J, Zhou C, Liao L, Jia M, Zhao Q, Cai H, Han ZC, Yang R, Chen G, Zhao RC. Proliferation and differentiation of bone marrow stromal cells under hypoxic conditions. Biochem Biophys Res Commun. 2006;347 (1):12-21.

36. Wiseman $H$, Halliwell $B$. Damage to DNA by reactive oxygen and nitrogen species: role in inflammatory disease and progression to cancer. Biochem J. 1996;313 (Pt 1):17-29.

37. Fahlenkamp AV, Rossaint $R$, Haase $H$, Al Kassam $H$, Ryang YM, Beyer C, Coburn M. The noble gas argon modifies extracellular signal-regulated kinase $1 / 2$ signaling in neurons and glial cells. Eur J Pharmacol. 2012;674(2-3): 104-11.

\section{Порівняльна оцінка ростових показників мезенхімальних стовбурових клітин Вартонового студня в різних газових сумішах}

Н. С. Шувалова, В. А. Кордюм

Мета. Оптимізувати культивування і порівняти вплив газових сумішей зі зниженим вмістом кисню, на основі азоту та аргону, на процеси проліферації в культурах мезенхімальних стовбурових клітин Вартонового студню (МСК-ВС). Методи. Протягом 5 пасажів. МСК-ВС культивували в газових сумішах на основі азоту (кисень - $3 \%$, вуглекислий газ $4 \%$, азот - $93 \%$ ) та аргону (кисень $-3 \%$, вуглекислий газ - 
4 \%, аргон - 93 \%). На кожному пасажі після 7 днів культивування підраховували кількість клітин, і визначали число подвоєнь культури. Результати. Чисельність клітин МСКВС, культивованих в сумішах, що містять 3 \% кисню, була вищою, ніж в загальноприйнятих умовах $\mathrm{CO}_{2}$-інкубатора. Рівень проліферації в суміші на основі аргону був нижчим, ніж в суміші на основі азоту, при цьому будучи вищим за такий для контрольних груп. Висновки. Культивування в газових сумішах, що містять 3 \% кисню, мало стимулюючий вплив на процеси проліферації МСК-ВС. Найбільш високий рівень мультиплікації спостерігали в сумішах на основі азоту.

К л юч о в і с л о в а: мезенхімальні стовбурові клітини, Вартонів студень, гіпоксія, фізіологічні концентрації кисню, проліферація

\section{Сравнительная оценка ростовых показателей мезенхимальных стволовых клеток Вартонова студня в различных газовых смесях}

Н. С. Шувалова, В. А. Кордюм

Цель. Оптимизация культивирования и сравнение влияния газовых смесей с пониженным содержанием кислорода на основе азота и аргона на процессы пролиферации в культуpax мезенхимальных стволовых клеток Вартонова студня (МСК-ВС). Методы. На протяжении 5 пассажей. МСК-ВС культивировали в газовых смесях на основе азота (кислород $3 \%$, углекислый газ - $4 \%$, азот - $93 \%$ ) и аргона (кислород $3 \%$, углекислый газ - $4 \%$, аргон - $93 \%$ ). На каждом пассаже после 7 дней культивирования подсчитывали количество клеток, и определяли число удвоений культуры. Результаты. Численность клеток МСК-ВС, культивированных в смесях, содержащих 3 \% кислорода, была выше, чем в общепринятых условиях $\mathrm{CO}_{2}$-инкубатора. Уровень пролиферации в смеси на основе аргона был несколько ниже, чем в смеси на основе азота, при этом будучи выше такого показателя для контрольных групп. Выводы. Культивирование в газовых смесях, содержащих 3 \% кислорода, оказывало стимулирующее влияние на процессы пролиферации МСК-ВС. Наиболее высокий уровень мультипликации наблюдали в смесях на основе азота.

Кл юч в ы е сл ов а: мезенхимальные стволовые клетки, Вартонов студень, гипоксия, физиологические концентрации кислорода, пролиферация.

Received 16.02.2015 